\title{
FAKTOR PENDORONG DAN PENARIK WISATAWAN TERHADAP JAZZ GUNUNG BROMO SEBAGAI ATRAKSI MUSIC TOURISM DI JAWA TIMUR
}

\author{
Dhea Azhar Melati Putri, Hindun Nurhidayati \\ Program Studi Pariwisata Fakultas Pariwisata Universitas Pancasila Jl. Serengseng Sawah, Jagakarsa, \\ Jakarta Selatan 12640
}

\begin{abstract}
ABSTRAK
Tujuan dari penelitian music tourism ini adalah untuk mengidentifikasi kondisi eksisting Jazz Gunung serta mengidentifikasi faktor pendorong dan penarik wisatawan terkait Jazz Gunung Bromo sebagai atraksi music tourism di Jawa Timur. Metode penelitian yang digunakan dalam penelitian ini adalah deskriptif kualitatif, dengan memanfaatkan data primer dan sekunder. Metode pengumpulan data yang digunakan adalah observasi, wawancara, penyebaran kuesioner, serta dokumentasi. Hasil penelitian ini menunjukkan bahwa kondisi eksisting Jazz Gunung Bromo sudah memenuhi indikator atraksi dari Walsh-Heron dan Stevens dalam Swarbrooke. Faktor pendorong yang paling dominan dalam mendorong wisatawan untuk menghadiri event Jazz Gunung Bromo adalah motivasi fisik, dan faktor penarik wisatawan yang membuat wisatawan tertarik untuk menghadiri Jazz Gunung Bromo adalah tempat serta pengisi acara.
\end{abstract}

Kata Kunci : Music tourism, atraksi, push and pull factor.

\section{PENDAHULUAN}

\section{Latar Belakang}

Pariwisata mulai menjadi kebutuhan juga gaya hidup bagi masyarakat. Oleh karena itu pariwisata sendiri mulai dikembangkan dan dipromosikan dengan gencar oleh pemerintah Indonesia. Pada tahun 2019 perolehan devisa dari sektor pariwisata diprediksi dapat mengungguli devisa dari sektor minyak dan gas (MIGAS) dengan target 20 juta wisatawan mancanegara (advertorial, CNN). Hal-hal tersebut dapat menjadi bukti keseriusan pemerintah dalam mengembangkan industri pariwisatanya. Berbagai program pun diluncurkan demi mencapai target tersebut.

Di Indonesia sendiri bentuk pariwisatanya cukup beragam dan yang paling ditonjolkan memang wisata alamnya. Maka dari itu program pemerintah untuk mendukung pencapaian target pada tahun 2019 ialah pembentukan 10 Bali baru (yang kini menjadi 10 destinasi prioritas) yang hampir semuanya merupakan wisata alam. Dalam sebuah laporan CNN Indonesia (2017), di tahun 2017 pemerintah mulai mendukung wisata bisnis atau wisata MICE (meetings, incentives, conventions, and exhibitions) untuk menggenjot wisatawan. Tetapi ada satu jenis wisata yang masih kurang mendapat perhatian dari pemerintah, yang bahkan disebut $\mathrm{CNN}$ Indonesia sebagai potensi yang diabaikan; wisata musik.

Inggris sudah menerapkan music tourism untuk menarik wisatawan baik lokal maupun mancanegara. Tahun 2013, UK Music selaku payung organisasi industri musik Britania Raya mulai menerbitkan Wish You Were Here: Music Tourism's Contribution to the UK Economy, sebuah laporan yang berisi tentang kontribusi wisata musik terhadap perekonomian negara tersebut. Dalam laporan UK Music tahun 2017, pada 2016 wisatawan yang dating mencapai angka 12,5 juta dengan 823.000 wisatawan musik mancanegara (UK Music, 2017). Perlu digarisbawahi bahwa jumlah tersebut menunjukkan wisatawan yang hanya datang ke festival tersebut, dan UK Music kemudian menyebut wisatawan- wisatawan itu sebagai music tourist. Angka ini menunjukkan betapa besarnya minat wisatawan terhadap wisata musik. Wisata musik sendiri merupakan salah satu jenis wisata minat khusus yang masih terdengar asing di telinga masyarakat Indonesia. Padahal Indonesia memiliki banyak sekali potensi untuk mendukung wisata musik. Definisi dari wisata musik itu sendiri menurut Wibisono (2009) ialah kegiatan pariwisata yang dilakukan berdasarkan dorongan musik, seperti mendatangi negara tertentu untuk menonton konser, atau pergi ke suatu daerah untuk berziarah ke situs musik terkenal.

Festival musik dan konser sendiri sudah bukanlah hal asing di Indonesia. Beberapa festival besar seperti Djakarta Warehouse Project, We The Fest, dan yang telah ada sejak tahun 2005 yaitu Java Jazz Festival sudah 
bertahun-tahun terselenggara di Jakarta. Konser serta festival tersebut menarik perhatian banyak orang terutama anak-anak muda yang merupakan penggemar musik dan wisatawan musik yang memang datang untuk menikmati musik tersebut.

Salah satu festival musik yang sudah cukup lama berlangsung di Indonesia adalah Jazz Gunung. Jazz Gunung merupakan sebuah pagelaran musik bertaraf internasional yang menampilkan komposisi jazz bernuansa etnik, digelar setiap tahun di daerah pegunungan Jawa Timur. Acara ini digagas oleh seorang bankir dan fotografer serta dua orang seniman; Sigit Pramono, Butet Kartaredjasa, dan Djaduk Ferianto. Acara yang sudah berlangsung sejak 2009 ini merupakan salah satu pionir berkembangnya festival musik yang dilaksanakan di alam terbuka di Indonesia.

Jawa Timur merupakan salah satu provinsi yang cukup gencar dalam pengembangan pariwisatanya. Hal ini terbukti, salah satunya, dengan terbentuknya Kota Wisata Batu, yang mulai menciptakan berbagai macam atraksi wisata buatan untuk menarik wisatawan lokal maupun mancanegara. Sektor pariwisata sendiri menyumbang Produk Domestik Regional Bruto yang cukup besar untuk Jawa Timur yaitu Rp 106 triliun (Republika) dengan kunjungan wisatawan mancanegara yang terus meningkat.

Jazz Gunung sendiri kini memiliki dua festival yang keduanya diadakan di Jawa Timur; "Jazz Gunung Bromo" yang merupakan pelopor Jazz Gunung dan "Ijen Summer Jazz" yang baru mulai diadakan di tahun 2014. Kedua festival tersebut memiliki konsep yang sama, yaitu harmonisasi antara alam, manusia, dan musik. Jazz Gunung Bromo yang kini memasuki satu dekade memiliki reputasi tersendiri sebagai "festival jazz 'tertinggi' di Indonesia" dengan menggelar festival di kaki gunung Bromo. Banyaknya peminat festival ini membuat pihak penyelenggara menambah hari demi mengakomodir pengunjung yang datang ke festival ke-10 ini. Lalu yang membuat festival ini makin unik untuk penyelenggaraan ke-10 adalah hadirnya "Jazz Gunung Pagi-Pagi" pada hari terakhir festival, di mana acara akan dimulai pada pukul 05.00 pagi agar pengunjung dapat menikmati matahari terbit Gunung Bromo yang terkenal sambal ditemani alunan musik jazz.

Dipilihnya Gunung Bromo sebagai lokasi untuk Jazz Gunung tak lepas dari rasa prihatin Sigit Pramono akan minimnya kunjungan wisatawan ke Gunung Bromo pasca erupsi Gunung Semeru di tahun 2008. Jazz Gunung pun digagas oleh Sigit Pramono, dibantu Butet Kartaredjasa dan Djaduk Ferianto, untuk menahan wisatawan lebih lama di kawasan Gunung Bromo. Sigit Pramono berkata bahwa ia ingin melakukan rebranding terhadap Gunung Bromo karena selama ini orang yang berkunjung keliru akan Bromo. Ia berkata bahwa bukanlah matahari terbit yang indah di Gunung Bromo, melainkan pantulan sinar matahari ke Gunung Bromo, Gunung Batok, Gunung Widodaren, dan Gunung Semeru (Frans Sartono, Kompas). Oleh karena itu, pada akhirnya di Jazz Gunung 2018 terbentuklah sebuah konsep yang menggabungkan trademark matahari terbit di Bromo, yaitu "Jazz Gunung Pagi-Pagi”. Hal ini akan memberi sebuah pengalaman baru bagi penggemar wisata alam serta penggemar musik.

Dalam music tourism pasti ada faktor yang menarik dan mendorong wisatawan untuk mengunjungi atraksinya. Faktor pendorong adalah faktor-faktor yang membuat wisatawan memiliki keinginan untuk bepergian sedangkan faktor penarik adalah hal-hal dari suatu destinasi yang dapat menarik wisatawan untuk mengunjunginya. Kedua hal ini dapat menggerakkan wisatawa untuk mengunjungi suatu destinasi.

Ketertarikan masyarakat terhadap musik yang dipercaya memiliki bahasa universal mampu memotivasi seseorang untuk melakukan perjalan dengan tujuan menikmati musik itu sendiri. Secara teoritis,

menurut Purwanto dalam Sari (2014) motivasi adalah segala sesuatu yang mendorong seseorang untuk bertindak melakukan sesuatu. Seseorang dapat melakukan sesuatu dengan satu atau lebih motivasi, dan motivasi tersebut dapat berbeda antara orang yang satu dan yang lain. Entah motivasi itu bertujuan untuk kepuasan diri sendiri, peningkatan gengsi, pelarian, atau hanya sekedar untuk berkomunikasi dengan orang baru, atau bahkan gabungan dari beberapa motivasi.

Motivasi pulalah yang dapat menggerakkan wisatawan untuk berkunjung ke suatu tempat untuk berwisata. Wisatawan merupakan pelaku utama pariwisata. Undang-undang RI nomor 10 tahun 2009 tentang Kepariwisataan mengatakan bahwa wisatawan adalah orang yang melakukan wisata.

\section{Tujuan Penelitian}

Tujuan dari penelitian ini adalah:

1. Mengidentifikasi kondisi eksisting Jazz Gunung Bromo sebagai atraksi music tourism di Jawa Timur. 
2. Mengidentifikasi faktor pendorong dan penarik wisatawan terkait Jazz Gunung Bromo sebagai atraksi music tourism di Jawa Timur.

\section{TINJAUAN PUSTAKA}

\section{Pengertian Atraksi}

Ismayanti (2010: 147) menyebut atraksi sebagai "daya tarik wisata" atau tourist attraction dan menjelaskan bahwa daya tarik wisata merupakan fokus utama penggerak pariwisata disebuah destinasi, yang diartikan daya tarik wisata sebagai penggerak utama yang memotivasi wisatawan untuk mengunjungi suatu tempat.

Walsh-Heron dan Stevens dalam Swarbrooke (2002:4) menyatakan bahwa sebuah atraksi ialah sebuah ciri dalam sebuah area yang merupakan tempat (place), venue, atau fokus dari suatu aktivitas dan Ditetapkan untuk menarik visitors/day visitors dari melakukan hal-hal berikut:

1. Penduduk atau populasi turis, dan dikelola sedemikian rupa Menyediakan pengalaman yang menyenangkan juga memuaskan dengan cara yang menyenangkan juga untuk pelanggan menghabiskan waktu senggang mereka.Dikembangkan untuk menyadari potensi tersebut.

2. Dikelola sebagai sebuah atraksi, menyajikan kepuasan kepada pelanggan.

3. Menyediakan fasilitas dan servis yang layak untuk memenuhi permintaan, kebutuhan, serta minat pengunjung.

4. Dapat membebankan biaya masuk ataupun tidak.

\section{Pengertian Music Tourism}

Connell dan Gibson (2005:1) mengatakan jika music tourism adalah, ketika orang berwisata, setidaknya dalam beberapa bagian, karena musik. Maksud dari Connell dan Gibson adalah ketika seseorang melakukan sebuah perjalanan atau berwisata dengan musik sebagai motivasinya, entah motivasi utama atau bukan, maka ia disebut melakukan wisata musik atau music tourism. Menurut Campbell (2011:7) music tourism melibatkan individu-individu yang berpergian ke tempat yang bukan merupakan tempat tinggalnya untuk mendengar pertunjukan live atau untuk mendapat pengalaman sejarah yang berhubungan dengan entah pembentukan atau pertunjukan musik.

\section{Pengertian Push and Pull Factor}

Dann (1977:186) menjelaskan bahwa faktor "penarik" ialah hal-hal yang menarik wisatawan ke resor tertentu (misalnya sinar matahari, laut, dan sebagainya), dan yang nilainya terlihat berada di objek perjalanan. Faktor "pendorong", di sisi lain, merujuk pada wisatawan sebagai subjek dan berurusan dengan factor-faktor yang mempengaruhi dirinya untuk bepergian (misalnya melarikan diri, nostalgia, dan lain- lain).

Crompton dalam Popp (2013:18) mengatakan dengan singkat bahwa faktor pendorong bersifat internal dan intrinsik sedangkan faktor penarik adalah karakteristik suatu destinasi yang membangkitkan keinginan untuk melakukan perjalanan di calon turis.

\section{Pengertian Motivasi Wisatawan}

Said dan Maryono (2018:3) mengutip pernyataan A.Beh dan Bruyere yang menyatakan bahwa motivasi dipahami sebagai kekuatan yang mendasari kebangkitan dan secara langsung mempengaruhi perilaku.

Menurut Handoko dalam Sari (2014) motivasi merupakan kekuatan penggerak dalam diri seseorang yang memaksanya untuk bertindak.

Dalam Ross (1998: 33), Mayo dan Jarvis menelaah ulang karya McIntosh yang mengelompokan motivasi menjadi empat, yaitu:

1. Physical or physiological motivation (Motivasi Fisik atau Motivasi Fisiologis)

Motivasi untuk mengistirahatkan fisik atau mengembalikan keadaan fisik yang lelah, ikut berolahraga, beristirahat dan bersantai, rekreasi pantai, atau melakukan sesuatu sebagai hiburan yang membuat tubuh tidak tegang, dan hal-hal dengan pertimbangan kesehatan.

2. Cultural Motivation (Motivasi Budaya)

Motivasi yang muncul dari keinginan untuk mengetahui negeri lain

- misalnya mempelajari seni, adatistiadat, tari, lukisan, dan agama dari suatu negara.

3. Social or Interpersonal Motivation (Motivasi Sosial atau Motivasi Antarpribadi)

Motivasi ini muncul atas keinginan bertemu dengan muka-muka baru; mengunjungi teman atau sanak saudara; melarikan diri dari kegiatan sehari-hari, keluarga atau tetangga; atau menciptakan sahabat baru.

4. Fantasy or Status and Prestige Motivation (Motivasi Fantasi atau Motivasi Status dan Martabat)

Motivasi ini muncul berdasarkan kebutuhan seseorang akan pengakuan, 
perhatian, penghargaan, dan reputasi. Serta adanya fantasi bahwa di daerah lain seseorang dapat melepaskan diri dari keseharian yang menjemukan.

\section{METODOLOGI PENELITIAN}

\section{Lokasi Penelitian}

Penelitian ini dilaksanakan di amfiteater terbuka Jiwa Jawa Resort Bromo, Sukapura, Probolinggo, Jawa Timur. Pengambilan data lapangan dilakukan selama 2 (dua) hari, yaitu pada 27 Juli dan 28 Juli 2018.

\section{Jenis Penelitian}

Penelitian ini menggunakan metode kualitatif. Bogdan dan Taylor dalam Moleong (2012:4) mendefinisikan metodologi kualitatif sebagai prosedur penelitian yang menghasilkan data deskriptif berupa kata-kata tertulis atau lisan dari orang-orang dan perilaku yang dapat diamati. Jenis dan Sumber Data

Data primer dalam penelitian ini besumber dari observasi lapangan, wawancara dengan narasumber, juga dari responden menggunakan kuesioner daring yang ditujukan kepada wisatawan lokal maupun mancanegara dan dokumentasi. Sedangkan data sekunder dalam penelitian ini diperoleh dari penelitian terdahulu seperti jurnal, skripsi, tesis, dan buku-buku maupun literature yang terkait dengan penelitian ini serta dari instansi lain.

\section{Teknik Penentuan Responden}

Penelitian ini akan menggunakan teknik simple random sampling untuk menentukan responden. Sugiyono (2018:82) menjelaskan bahwa simple random sampling disebut simple (sederhana) karena pengambilan anggota sampel dari populasi dilakukan secara acak tanpa memperhatikan strata yang ada dalam populasi itu. Teknik ini dipilih karena informan yang dipilih disesuaikan dengan kebutuhan peneliti. Jumlah responden yang diambil adalah sebanyak 40 responden.

Dari penentuan informan untuk diwawancarai dan digali informasinya, penyelenggara event Jazz Gunung Bromo, wisatawan, dan masyarakat sekitar dipilih sebagai narasumber.

\section{Analisis Data}

Teknik analisis data yang digunakan dalam penelitian ini ialah langkah-langkah analisis data menurut Miles dan Huberman (1992). dimana terdapat tahap pengumpulan data, reduksi data, penyajian data, dan penarikan kesimpulan/verifikasi. Kemudian peneliti menggunakan teknik trianggulasi untuk menguji keabsahan data yang didapat. Penelitian ini juga menggunakan skala likert untuk mengukur motivasi wisatawan.

\section{HASIL DAN PEMBAHASAN}

\section{Kondisi Eksisting Jazz Gunung Bromo}

Jazz Gunung Bromo merupakan sebuah event yang diselenggarakan di amfiteater terbuka Jiwa Jawa Resort Bromo, yang terletak di ketinggian 2000 meter di atas permukaan laut. Acara musik tahunan ini pun dijuluki sebagai "Festival Jazz 'Tertinggi' di Indonesia" dan tahun ini merupakan acara kesepuluhnya. Jazz Gunug Bromo 2018 yang bertajuk "1 Jazzawarsa" diselenggarakan pada 27-29 Juli 2018.Event yang awalnya hanya digelar di halaman hotel Java Banana Lodge (sekarang berganti nama menjadi Jiwa Jawa Resort) dengan 200-250 pengunjung, kini sudah memiliki venue tetap, yaitu amfiteater terbuka beralaskan rumput dan bebatuan, beratapkan langit, dan berlatarkan gunung pemandangan Gunung Bromo, dengan panggung terbuka berhiaskan dekorasi yang terbuat dari bambu hasil karya seniman lokal asal Yogyakarta yang bisa memuat sampai sekitar 2000 orang.

Jazz Gunung Bromo masih menargetkan wisatawan domestik. Lebih spesifiknya, Jazz Gunung menargetkan "orang yang menyukai perjalanan (traveler), orang yang menyukai musik, orang yang menyukai fotografi, atau gabungan dari dua atau ketiga-tiganya", seperti yang diutarakan ketua pelaksana Jazz Gunung Bromo 2018, Bagas, dalam wawancara. Namun walau begitu kehadiran wisatawan mancanegara tetap dapat terlihat setiap tahunnya, begitu pula pada acara ke- 10 ini.

Wisatawan yang datang cenderung mengalami peningkatan setiap tahunnya. Acara ini pada umumnya diselenggarakan pada hari Jumat dan Sabtu sore hingga malam hari. Tetapi pada dasarnya acara tersebut lebih ramai di hari Sabtu, karena orang-orang cenderung lebih luang pada malam Minggu. Dalam pelaksanaan Jazz Gunung Bromo 2018 diadakan penambahan hari yaitu di hari Minggu untuk mengatasi antusiasme wisatawan, hal tersebut dikarenakan pada tahun 2017 pihak penyelenggara harus menolak wisatawan datang untuk menghadiri event tersebut karena kapasitas venue yang tidak memadai. Penambahan hari dianggap merupakan solusi yang tepat karena kapasitas amfiteater sendiri yang hanya dapat memuat sekitar 2000 orang, dan perluasan venue sangat tidak memungkinkan mengingat di sekitar venue adalah jurang. 


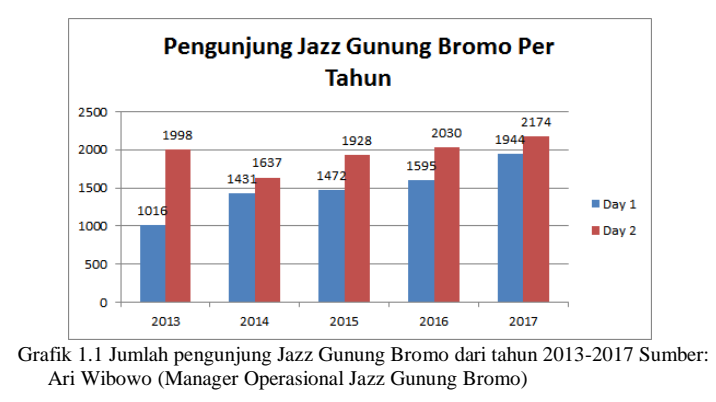

Manajer operasional Jazz Gunung Bromo 2018, Ari Wibowo, menambahkan bahwa Jazz Gunung Bromo ini sendiri berdampak kepada masyarakat sekitarnya. Pertama, dengan adanya event Jazz Gunung Bromo ini selalu berdampak kepada tingkat okupansi penginapan di sekitar lokasi karena resort tempat event ini diselanggarakan tidak mungkin dapat menampung seluruh pengunjung, pengisi acara, dan panitia serta staff. Lalu pihak penyelenggara pun memperbolehkan masyarakat sekitar untuk berjualan di area sekitar lokasi untuk memenuhi kebutuhan wisatawan, seperti makanan, minuman, sampai aksesoris untuk menghangatkan tubuh mengingat udara pegunungan yang dingin. Selain itu, dalam pelaksanaannya pihak penyelenggara memberdayakan masyarakat sekitar dengan cara melibatkan dalam kepanitiaan sehingga diharapkan hal tersebut dapat memberikan keuntungan bagi masyarakat sekitar baik secara ekonomi ataupun peningkatan pengalaman.

\section{Karakteristik Responden}

Berdasarkan data yang dikumpulkan melalui kuesioner daring sebagai alat untuk mengumpulkan data yang disebarkan ke 40 wisatawan yang menghadiri Jazz Gunung Bromo 2018, didapatkan hasil bahwa wisatawan yang datang didominasi oleh:

Wisatawan nusantara yang berasal dari Jawa Timur dengan presentase sebesar $42,5 \%$. Adapun wisatawan mancanegara didominasi oleh wisatawan asal Malaysia dengan presentase sebesar 12,5\%. Responden didominasi oleh wisatawan usia 18-27 tahun dengan presentase $47,5 \%$, berjenis kelamin perempuan sebesar 55\%, dengan 55\%-nya telah selesai menempuh pendidikan S1, dan berprofesi sebagai karyawan/karyawati dengan presentase $50 \%$. $67,5 \%$ responden menginap di homestay/guesthouse penduduk selama acara berlangsung dan mereka yang menginap lebih banyak yang tinggal selama 2 hari 1 malam dengan presentase $52,8 \%$. Mayoritas responden datang ke daerah Bromo adalah untuk menghadiri Jazz Gunung Bromo 2018 yang terbukti dengan presentase $92,5 \%$ dan $77,5 \%$ datang dengan teman/rekan. $60 \%$ responden mendapatkan informasi mengenai Jazz Gunung Bromo dari internet dan media elektronik. Jazz Gunung Bromo 2018 didominasi oleh firsttimer dengan presentase sebesar $65 \%$ dan $50 \%$ responden hanya menghadiri satu dari

tiga hari rangkaian kegiatan Jazz Gunung Bromo.

\section{Jazz Gunung Bromo Sebagai Atraksi Music Tourism di Jawa Timur}

Pada tahun 2018, Jazz Gunung Bromo telah menyelenggarakan event kesepuluhnya, tepatnya pada pada tanggal 27 hingga 29 Juli 2018. Meskipun demikian, masih belum ada penelitian yang signifikan mengenai Jazz Gunung Bromo sebagai atraksi music tourism. Berdasarkan hal tersebut peneliti bertujuan untuk mengindentifikasi Jazz Gunung Bromo sebagai atraksi dari music tourism sesuai dengan teori Walsh-Heron dan Stevens dalam Swarbrooke (2002:4). Dikatakan bahwa atraksi ialah suatu ciri dalam sebuah area yang merupakan tempat (place), venue, atau fokus dari suatu aktivitas dengan pendekatan sebagai berikut:

1) Ditetapkan untuk menarik visitors/day visitors dari wisatawan dengan minat terhadap music tourism, dan dikelola sedemikian rupa.

Guna meningkatkan kembali angka kunjungan Gunung Bromo yang sempat menurun akibat letusan, Sigit Pramono, seorang banker dan fotografer, menggagas sebuah event musik yang berbeda dengan mengajak dua orang seniman; Butet Kartaredjasa, dan Djaduk Ferianto. Dari gagasan tersebut lahirlah Jazz Gunung Bromo dengan konsep unik. Makna unik dapat dilihat dari pelaksanaannya yang terletak di posisi 2000 mdpl, dimana tidak ada event musik yang diselanggarakan di ketinggian tersebut. Berdasarkan keunikan tersebut, pada tahun 2013 event ini berhasil menarik minat sebanyak 3014 pengunjung.

Menurut penjelasan Bagas sebagai ketua pelaksana event Jazz Gunung Bromo 2018, event ini merupakan event musik yang memiliki target untuk memikat wisatawan yang memiliki kesenangan terhadap musik, travelling, dan fotografi. Joie, seorang wisatawan yang memang seorang penggemar musik asal Singapura, menyatakan dalam wawancara bahwa ia sengaja datang dari negara asalnya dengan temannya murni untuk mendatangi event Jazz Gunung Bromo dan ia tidak keberatan berpergian untuk menonton sebuah event musik. Dengan venue alami seperti milik amfiteater Jiwa Jawa Resort tentu saja membuat Joie tertarik untuk menonton, sebagai ajang untuk melarikan diri dari kesehariannya di Singapura. Kemudian yang dimaksud dengan dikelola sedemikian rupa 
adalah event ini dikelola untuk

mempertahankan keunikannya. Pengelola mempertahankan konsep event yang menyatu dengan alam dengan cara meningkatkan kualitas tanpa merusak keasrian kawasan Gunung Bromo. Hal ini didukung dengan konsep amfiteater terbuka yang alami dan panggung yang selalu menggunakan aksen bambu sebagai dekorasi.

\section{2) Menyediakan}

pengalaman menikmati music tourism yang unik, menarik, serta memuaskan dengan cara yang menyenangkan juga untuk wisatawan menghabiskan waktu senggang mereka

Jazz Gunung Bromo telah menawarkan konsep yang unik karena wisatawan dapat berkesempatan mendapatkan pengalaman menonton rangkaian pertunjukan musik jazz di ketinggian 2000 mdpl sambil merasakan dinginnya udara pegunungan. Ditambah dengan panggung yang berlatarkan Gunung Bromo, beratapkan langit, dan beralaskan rumput dan bebatuan yang benar-benar alami, yang hanya dapat ditemukan dalam rangkaian acara Jazz Gunung. Sentuhan etnik pun selalu diberikan di setiap event- nya yang dipadukan dengan musik jazz yang tentunya akan memberikan pengalaman tersendiri kepada wisatawan.

Tung dan Ritchie (2011:1371) membahas mengenai pengelolaan pengalaman yang mengesankan dengan mengutip teori bidang milik Pine dan Gilmore. Mereka mengatakan bahwa pengalaman eskapis meliputi "imersi pelanggan yang lebih besar... baik partisipasi aktif dan imersi dalam pengalaman". Venue outdoor Jazz Gunung Bromo membuat wisatawan dapat merasakan pengalaman menikmati Gunung Bromo dengan cara yang berbeda yang dikemas dalam wisata musik.

Berdasarkan keunikan event tersebut, wisatawan dengan ketertarikan terhadap musik pun lebih memilih untuk menghabiskan waktu senggang mereka di sana. Seperti Nabila Anggun yang dalam wawancaranya mengatakan bahwa alasannya menghadiri event tersebut ialah karena rasa penasaran atas atmosfir yang disuguhkan oleh pihak Jazz Gunung. Untuk ukuran wisatawan yang tertarik dengan unsur budaya, Nabila merasa puas dengan perpaduan musik Jazz dan musik etnik yang dimainkan. Kepuasan wisatawan pun dapat dilihat dari imersi wisatawan terhadap event Jazz Gunung Bromo ketika acara berlangsung dan apakah wisatawan tersebut merupakan repeater yang artinya sudah pernah datang ke acara tersebut. Dari lima narasumber yang diwawancara di tempat, dua di antaranya merupakan sudah pernah mengunjungi Jazz Gunung Bromo sebelumnya. Keduanya merupakan penggemar musik yang gemar menghabiskan waktu senggangnya untuk merasakan pengalaman menonton konser musik Jazz di alam terbuka. Suhu yang dingin pun bukan menjadi halangan karena menurut mereka, hal tersebut akan menjadi pengalaman yang tak terlupakan.

3) Dikembangkan untuk menyadari potensi music tourism

Jazz Gunung Bromo pertama kali digagas di tahun 2009 untuk meningkatkan kembali kunjungan ke daerah Bromo serta memasyarakatkan kembali musik Jazz. Kala itu Jazz Gunung Bromo diadakan hanya satu hari di halaman Java Banana Lodge dengan kapasitas 200-250 orang. Di tahun tersebut juga pihak pengelola membuka akun Facebook sebagai media untuk promosi.

Di tahun 2010 pihak pengelola membuka akun Twitter sebagai media promosi agar dapat menjangkau kalangan yang lebih luas.

Pada tahun 2011 Jazz Gunug Bromo Dapat dikatakan berkontribusi untuk pariwisata daerah Bromo dengan tetap melangsungkan acara pada 9 Juli 2011 untuk meyakinkan wisatawan bahwa Bromo sudah aman untuk dikunjungi mesikipun di awal tahun sempat terjadi letusan.

Menambah hari pelaksanaan menjadi dua hari pada 2012 untuk mengatasi minat wisatawan yang meningkat setiap tahunnya. Membuka akun Youtube untuk membagikan dokumentasi acara berupa video dan membuka akun Instagram untuk menjangkau kalangan yang lebih luas.

Di tahun 2013 lokasi acara dipindahkan ke amfiteater Jiwa Jawa Resort yang dapat mengakomodir sekitar 2000 orang. Dengan waktu pelaksanaan yang tetap dua hari.

Kemudian di tahun 2017 Pihak Jazz Gunung Bromo menginisiasi sebuah forum event Jazz se-Indonesia sebagai bentuk dukungan terhadap music tourism, khususnya Jazz, di Indonesia. Forum ini dibuat untuk berkoordinasi dalam banyak hal terutama waktu penyelenggaraan dan pengisi acara agar tidak saling bertabrakan 
antara satu acara dengan acara lainnya.

Pada tahun 2018 Acara berlangsung selama tiga hari untuk mengatasi minat wisatawan. Dengan mengadakan hari ketiga di pagi hari sebagai bentuk inovasi.

4) Dikelola sebagai atraksi music tourism, menyajikan kepuasan kepada wisatawan

Pada awalnya, wisatawan harus datang ke lokasi untuk mendapatkan tiket untuk acara Jazz Gunung Bromo dan untuk mendapatkan tempat duduk terbaik, wisatawan harus datang lebih awal. Tiket pun masih berupa selembar kertas yang akan dirobek ketika wisatawan memasuki area vепие. Lokasi pun masih di halaman Jiwa Jawa Resort (yang dulu masih bernama Java Banana Lodge) dengan panggung sederhana. Promosi mengenai event Jazz Gunung pun masih terbatas. Di tahun 2009 Jazz Gunung Bromo belum memanfaatkan media sosial secara maksimal. Pengisi acara di kala itu juga masih sedikit.

Jazz Gunung Bromo sekarang sudah menerapkan sistem yang lebih mandiri pada penjualan tiketnya dengan memanfaatkan internet. Tiket dapat dipesan di situs milik Jazz Gunung (http://www.jazzgunung.com/) dan sudah dapat dipesan beberapa bulan sebelumnya dengan pratinjau perkiraan pemandangan dari setiap kategori seat.

Bentuk tiket sudah berupa gelang dengan warna yang berbeda untuk setiap kategori. Bentuk tiket seperti ini mempermudah staff untuk mengidentifikasi wisatawan juga mempermudah wisatawan untuk keluarmasuk dari venue. Walau sudah menerapkan sistem online ticketing, pihak Jazz Gunung tetap menyediakan booth pembelian tiket di dekat venue bagi yang ingin membeli tiket on the spot.

Lokasi acara juga berpindah ke amfiteater untuk mengakomodir lebih banyak pengunjung serta memberi kenyamanan menonton yang lebih baik bahkan dari jauh (dikarenakan posisi tempat duduk yang berundak). Panggung yang lebih megah yang dilengkapi dengan tata lampu yang membuat panggung lebih meriah serta sound system dengan suara jernih yang dibuat khusus (custom made) untuk Jazz Gunung untuk menunjang penampilan pengisi acara.

Untuk mempromosikan acara pun Jazz Gunung Bromo sudah mulai menggunakan media sosial seperti Twitter, Youtube, Facebook dan Instagram. Akunakun ini dibuat untuk menjangkau kalangan yang lebih luas serta mempermudah wisatawan untuk mendapatkan informasi.

5) Menyediakan fasilitas dan pelayanan yang layak untuk memenuhi permintaan, kebutuhan, serta minat wisatawan terhadap music tourism

Bagi wisatawan yang datang dari daerah asal yang cukup jauh, pihak pengelola memberikan berbagai macam pilihan akomodasi. Pihak Jazz Gunung bekerja sama dengan pihak Jiwa Jawa Resort karena pada dasarnya event Jazz Gunung Bromo memang diadakan di amfiteater milik Jiwa Jawa Resort, sehingga pihak Jazz Gunung dapat bekerjasama dengan pihak resort untuk menyediakan potongan harga bagi wisatawan yang menginap di Jiwa Jawa Resort. Tidak hanya itu, piha

$\mathrm{k}$ penyelenggara bekerja sama pula dengan Persatuan Hotel dan Restoran Indonesia (PHRI), yang membuat mereka dapat membantu mencari alternatif penginapan untuk wisatawan serta membuat beberapa pilihan paket menginap.

Pihak Jazz Gunung memberi informasi kepada wisatawan melalui akun media sosial Instagram dan situs resmi mereka mengenai penginapan-penginapan yang masih menyediakan kamar menjelang waktu pelaksanaan acara. Penyelenggara juga menyediakan paket antar-jemput bagi wisatawan dari luar Malang yang datang melalui bandara. Wisatawan yang membeli paket ini akan dijemput dari bandara menuju penginapan, lalu dijemput kembali dari penginapan menuju lokasi Jazz Gunung Bromo, dan kemudian diantar kembali ke penginapan dan/atau ke bandara ketika wisatawan tersebut akan pulang. Selain itu, pihak penyelenggara pun membagikan informasi mengenai bagaimana cara untuk menuju ke lokasi di situs resmi mereka yaitu http://www.jazzgunung.com/ serta di media sosial resmi Jazz Gunung.

Untuk venue sendiri, amfiteater terbuka tempat diselenggarakannya Jazz Gunung Bromo 2018 sudah memiliki fasilitas yang memadai. Di amfiteater tersebut tersedia toilet yang bersih untuk pengunjung dan backstage yang memadai untuk performer. Venue juga dilengkapi CCTV untuk keamanan. Di seberang venue terdapat rest 
area yang nyaman, yang memiliki sebuah galeri foto di mana foto-foto hasil bidikan Sigit Pramono, kafe, toko cinderamata, serta ticket booth bagi yang ingin membeli tiket di tempat (on the spot).

Kemudian untuk memenuhi kebutuhan akan amenitas lain, pihak Jazz Gunung menyediakan stall makanan yang menjual camilan dan minuman hangat di dalam venue. Di sekitar venue terdapat warungwarung makan yang dikelola oleh masyarakat sekitar yang memang sudah mendapat izin. Selain makanan, beberapa masyarak sekitar juga menjual aksesoris untuk menghangatkan tubuh seperti topi, sarung tangan, dan syal.

Selain itu, untuk menjaga agar wisatawan tetap nyaman ketika menyaksikan pertunjukan, pihak penyelenggara menyediakan penghangat yang dikeluarkan ketika langit mulai gelap. Penghangat tersebut diletakkan di satu titik di setiap section tempat duduk serta di dekat panggung dan di belakang panggung. Untuk acara di hari terakhir yang dilaksanakan pada pagi hari, pihak Jazz Gunung membagikan secangkir kopi panas untuk menghangatkan tubuh kepada wisatawan yang hadir.

6) Dapat membebankan biaya masuk ataupun tidak

Jazz Gunung Bromo membuka dua kali penjualan tiket secara online, yaitu Early Bird yang dibuka pada bulan Januari sampai Maret, dan Normal yang dibuka dari bulan April sampai hari pertama event berlangsung. Ada empat kategori tiket yang dapat dibeli, yaitu:

Tabel 1.1 Harga Tiket Jazz Gunung Bromo 2018

\begin{tabular}{|c|c|}
\hline VVIP & Rp $1.050 .000,00$ \\
\hline VIP A & $\operatorname{Rp~} 750.000,00$ \\
\hline VIP B & $\operatorname{Rp~} 600.000,00$ \\
\hline Festival & $\operatorname{Rp~} 425.000,00$ \\
\hline
\end{tabular}

Sumber: Situs resmi Jazz Gunung (store.jazzgunung.com)

Tiket-tiket tersebut dapat dibeli di tempat (on the spot) ketika acara berlangsung, namun dengan harga $\mathrm{Rp}$ 50.000,00 lebih mahal.

\section{Push Factor}

Motivasi merupakan faktor pendorong dominan dari seorang wisatawan. Berikut adalah hasil analisis pada faktor pendorong berupa motivasi menurut McIntosh yang diperoleh dengan menggunakan Skala Likert. Hasil analisis ini didapat dari kuesioner yang diisi oleh 40 responden yang menghadiri Jazz Gunug Bromo 2018.

\section{Motivasi Fisik}

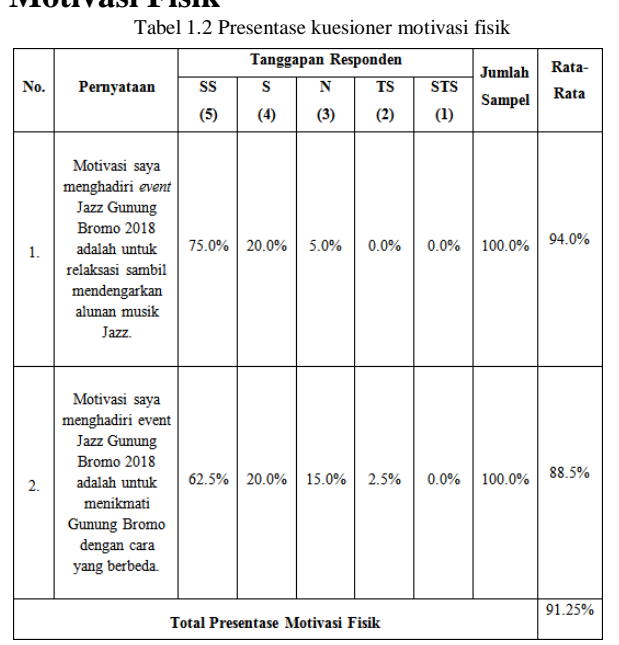

Berdasarkan hasil kuesioner pada tabel 1.2 yang diisi oleh 40 responden yang menghadiri Jazz Gunung Bromo 2018, tingkat motivasi fisik tertinggi terdapat di item pertama, dengan presentase total sebesar 94\%. Hal ini berarti kebanyakan wisatawan menghadiri Jazz Gunung Bromo 2018 adalah untuk relaksasi sambil mendengarkan alunan musik jazz. Sedangkan item kedua yang menyatakan wisatawan menghadiri Jazz Gunung Bromo 2018 untuk menikmati Gunung Bromo dengan cara yang berbeda memiliki total presentase sebesar $88.5 \%$.

Hasil tabel 1.2 menyatakan bahwa keseluruhan skor dari sub-variabel motivasi fisik adalah $91.25 \%$. Dapat dikatakan bahwa wisatawan setuju jika motivasi terbesar mereka untuk menghadiri event Jazz Gunung Bromo 2018 adalah untuk menikmati alunan musik Jazz sambil merelaksasikan diri. Dengan ini terbukti pula bahwa faktor pendorong terbesar wisatawan adalah musik, sehingga wisatawan tersebut dapat disebut sebagai music tourists.

Alasan dari presentase $94 \%$ wisatawan menghadiri event Jazz Gunung Bromo 2018 untuk relaksasi sambil mendengarkan alunan musik Jazz adalah karena mereka merasa tenang dan rileks dengan mendengarkan alunan musik jazz sambil menikmati pemandangan alam. Wisatawan menganggap kegiatan ini merupakan healing dari kehidupan sehari-hari.

\section{Motivasi Budaya}

Tabel 1.3 Presentase kuesioner motivasi budaya 


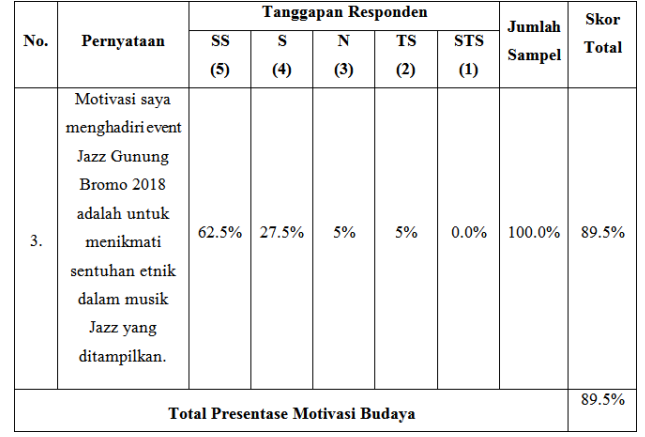

Hasil kuesioner motivasi budaya memperoleh presentase sebesar $89.5 \%$. Dengan wisatawan dominan sangat setuju dengan indikator dari sub-variabel terebut. Para wisatawan yang menghadiri event ini ingin menyaksikan sentuhan etnik apa yang disajikan dalam event tersebut.

Skor total keseluruhan dari sub-variabel motivasi budaya adalah $89.5 \%$. Dengan ini dapat dikatakan bahwa wisatawan yang datang ke event Jazz Gunung Bromo 2018 digerakkan oleh keinginan untuk menikmati sentuhan etnik dalam musik Jazz yang ditampilkan yang memang selalu ada di setiap tahunnya.

Motivasi Sosial atau Antarpribadi

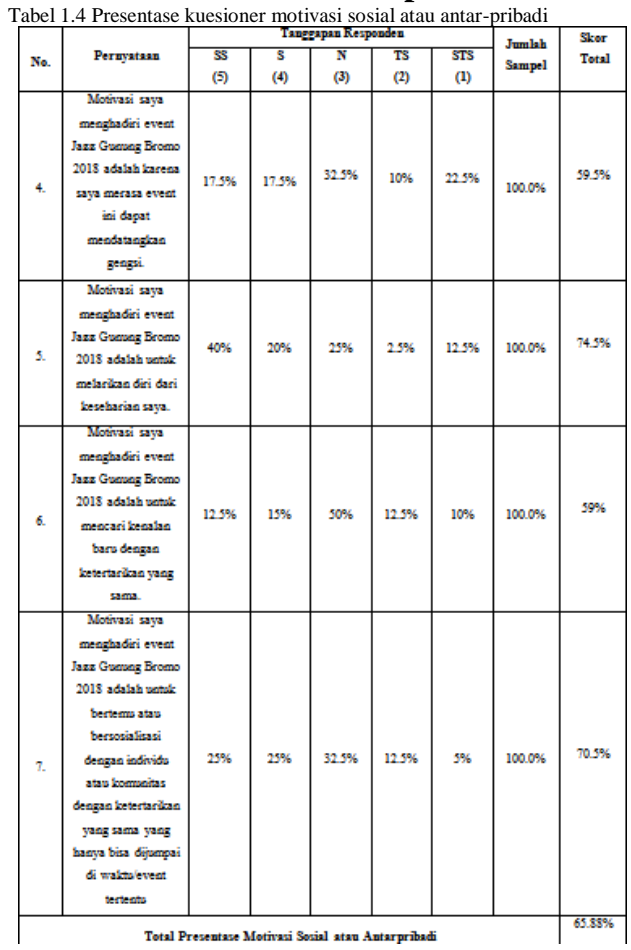

Berdasarkan hasil kuesioner pada tabel 1.4, motivasi sosial atau interpersonal tertinggi ada pada item nomor lima dengan presentase sebesar $74.5 \%$, yang menyatakan bahwa wisatawan termotivasi untuk menghadiri event Jazz Gunung Bromo 2018 adalah untuk melarikan diri dari kesehariannya. Selanjutnya adalah item nomor tujuh dengan presentase sebesar $70.5 \%$, yaitu motivasi untuk menghadiri event Jazz Gunung Bromo 2018 untuk bertemu atau bersosialisasi dengan individu atau komunitas dengan ketertarikan yang sama yang hanya bisa dijumpai di waktu atau event tertentu. Kemudian dengan presentase sebesar $59.5 \%$ dengan item nomor empat, bahwa motivasi wisatawan menghadiri event Jazz Gunung Bromo 2018 adalah karena saya merasa event ini dapat mendatangkan gengsi. Dan di posisi terakhir adalah item nomor enam dengan presentase $59 \%$ yang menyatakan bahwa motivasi wisatawan menghadiri event Jazz Gunung Bromo 2018 adalah untuk mencari kenalan baru dengan ketertarikan yang sama.

Dari tabel tersebut dapat diketahui bahwa total skor dari sub-variabel motivasi sosial atau interpersonal adalah $65.88 \%$. Hasil tersebut membuktikan bahwa wisatawan yang datang menyetujui jika motivasi tertinggi mereka menghadiri event Jazz Gunung Bromo 2018 adalah untuk melarikan diri dari kesehariannya.

Wisatawan merasa jenuh dengan kesehariannya dan ingin melarikan diri untuk dari rutinitas yang menjemukan, walau hanya sebentar, untuk menyegarkan pikiran sebelum kembali ke lingkaran rutinitasnya masing-masing.

\section{Motivasi Fantasi atau Status dan Martabat}

Tabel 1.5 Presentase kuesioner motivasi fantasi atau status dan

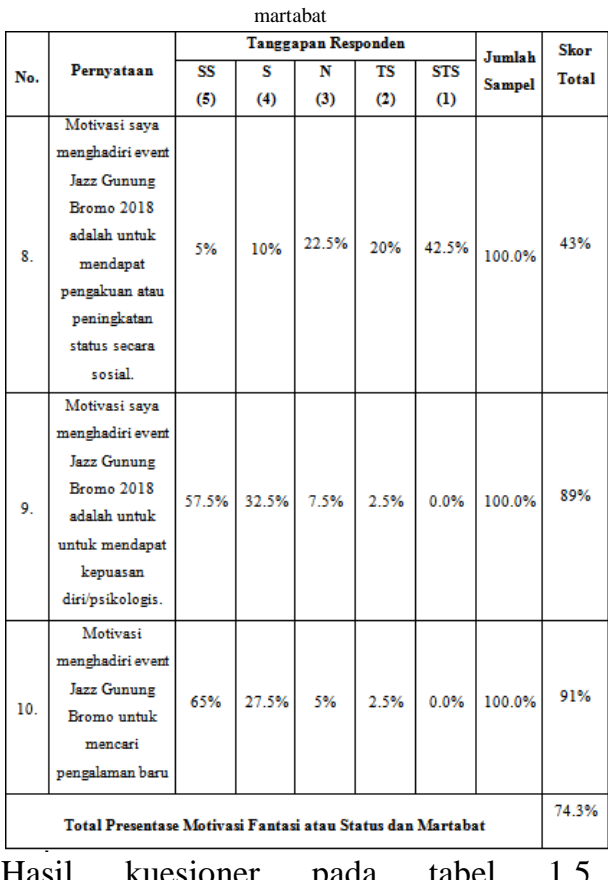

Hasil kuesioner pada tabel 1.5 memperlihatkan bahwa motivasi fantasi atau status dan martabat tertinggi ada pada item nomor sepuluh dengan presentase sebesar $91 \%$, yang menyatakan bahwa motivasi wisatawan menghadiri Jazz Gunung Bromo 
2018 adalah untuk mendapat kepuasan diri atau psikologis. Kemudian item nomor delapan dengan presenttase $43 \%$ yang menyatakan bahwa motivasi wisatawan menghadiri event Jazz Gunung Bromo 2018 adalah untuk mendapat pengakuan atau peningkatan status secara sosial.

Secara keseluruhan skor total dari subvariabel motivasi fantasi atau status dan martabat adalah 66\%. Dengan demikian wisatawan yang menghadiri event Jazz Gunug Bromo 2018 menyetujui bahwa dalam subvariabel motivasi fantasi atau status dan martabat tertinggi ada pada item nomor sepuluh. Wisatawan cenderung datang untuk mencari pengalaman baru yang kemungkinan tidak bisa didapatkan di daerah asal atau di kehidupan sehari-harinya.

\section{Pull Factor}

Jika ada faktor pendorong, tentu ada pula faktor penarik wisatawan ke suatu destinasi atau atraksi. Dalam kuesioner daring yang diisi oleh 40 responden yang menghadiri Jazz Gunung Bromo 2018 responden menyebutkan faktor penarik yang membuat mereka bergerak untuk melakukan perjalanan demi menghadiri event tersebut, yaitu pengisi acara dan venue.

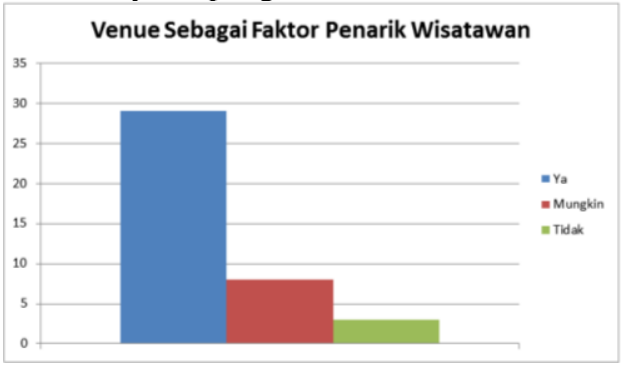

Grafik 1.2 Grafik venue sebagai faktor penarik wisatawan ke Jazz Gunung Bromo 2018

Sumber: Hasil pengolahan data primer

Berdasarkan hasil kuesioner di atas mengenai peran venue sebagai faktor penarik wisatawan. $72.5 \%$ responden mengatakan bahwa venue Jazz Gunung Bromo merupakan salah satu faktor yang menggerakkan para wisatawan untuk mengunjungi event Jazz Gunung Bromo 2018. 20\% responden menyatakan bahwa venue mungkin merupakan salah satu faktor yang menggerakkan para wisatawan untuk mengunjungi event Jazz Gunung Bromo 2018 dan $7.5 \%$ responden menyatakan bahwa venue tidak mempengaruhi wisatawan untuk mengunjungi event Jazz Gunung Bromo 2018. Oleh karena itu dapat ditarik kesimpulan bahwa venue dari Jazz Gunung Bromo merupakan faktor penarik yang kuat untuk menarik wisatawan menghadiri Jazz Gunung Bromo. Hal ini dikarenakan banyak yang menganggap bahwa venue dari Jazz
Gunung Bromo unik dan berbeda dari yang lain. Para wisatawan ingin merasakan menonton pertunjukan musik di venue yang terletak di ketinggian 2000 meter di atas permukaan laut dengan hawa yang dingin dengan pemandangan alam yang indah dan Gunung Bromo yang melatari panggung acara.

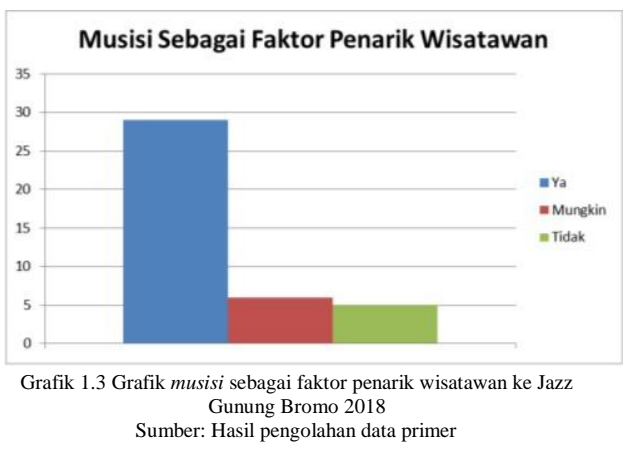

Grafik di atas menunjukkan hasil kuesioner mengenai peran musisi atau pengisi acara sebagai faktor penarik wisatawan ke event Jazz Gunung Bromo 2018. 72.5\% responden menyatakan bahwa musisi atau pengisi acara memjadi daya tarik yang sama besar untuk mengunjungi Jazz Gunung Bromo. 15\% responden menyatakan bahwa musisi atau pengisi acara mungkin berpengaruh pada keputusan berkunjung mereka dan $12.5 \%$ responden menyatakan bahwa musisi atau pengisi acara bukan merupakan daya tarik bagi wisatawan. Oleh karena itu dapat disimpulkan bahwa musisi atau pengisi acara memiliki peran untuk menarik wisatawan untuk berkunjung ke event Jazz Gunung Bromo 2018.

\section{Music Tourism di Indonesia}

Dalam kuesioner daring yang disebarkan kepada 40 responden terdapat pertanyaan "Apakah Jazz Gunung Bromo dapat menjadi atraksi unggulan music tourism di Indonesia?" dan didapatkan hasil berupa $97.5 \%$ responden menjawab ya dan $2.5 \%$ responden menjawab mungkin. Hasil tersebut disebabkan oleh responden yang berpendapat bahwa Jazz Gunung Bromo merupakan event musik yang dikemas dengan unik.

Selain itu, dalam kuesioner terdapat pula pertanyaan mengenai "Apakah music tourism dapat menjadi alternatif pariwisata baru di Indonesia?" dan hasil dari 40 responden yang mengisi, $85 \%$ responden memilih ya dan $15 \%$ responden memilih mungkin. Mereka setuju dan menyambut positif music tourism sebagai alternatif pariwisata baru di Indonesia.

Pariwisata dan musik sendiri sesungguhnya adalah dua hal yang saling melekat. Banyak orang penyuka musik yang juga menyukai 
travelling, oleh karena itu perpaduan keduanya merupakan hal yang sangat bagus untuk meningkatkan kunjungan, karena banyak penggemar musik yang rela melakukan perjalanan jauh hanya untuk mendapatkan suasana menonton pertunjukan musik yang berbeda. Selain itu, kebanyakan dari responden beralasan bahwa musik merupakan pelepas penat yang dapat dinikmati berbagai kalangan dan usia. Ditambah dengan ide-ide kreatif dan pengemasan yang baik tentunya dapat menghasilkan event musik yang berkelas. Dan music tourism sendiri dapat dijadikan wadah untuk meng-explore musisi, alat musik, serta jenis musik yang ada di Indonesia. Bahkan dapat menjadi wadah untuk mengenalkan Indonesia kepada wisatawan mancanegara.

Jazz Gunung Bromo sendiri sudah dapat menjadi pionir dari music tourism di Indonesia karena pengemasannya yang menarik. Kreativitas yang disajikan dapat membuat wisatawan terkagum-kagum dan tertarik untuk kembali menghadiri event tersebut di tahun berikutnya. Servis dan fasilitas yang disediakan pun dirasa memuaskan bagi wisatawan yang hadir.

\section{SIMPULAN}

\section{Simpulan}

Berdasarkan hasil penelitian yang telah dilakukan dengan menggunakan analisis kualitatif deskriptif serta skala likert untuk mengetahui motivasi wisatawan menghadiri Jazz Gunung Bromo 2018, dapat ditarik kesimpulan bahwa kondisi eksisting Jazz Gunung Bromo sudah memenuhi indikator teori atraksi menurut Walsh-Heron dan Stevens dalam Swarbrooke (2002), yang berarti Jazz Gunung Bromo sudah menarik visitors/day visitors. Sudah menyediakan pengalaman menikmati music tourism yang unik, menarik, memuaskan, juga menyenangkan untuk wisatawan

menghabiskan waktu senggang mereka. Sudah dikembangkan untuk menyadari potensi music tourism, sudah dikelola sebagai atraksi music tourism, menyajikan kepuasan kepada wisatawan, dan sudah menyediakan fasilitas dan pelayanan yang layak untuk memenuhi permintaan, kebutuhan, serta minat wisatawan terhadap music tourism, juga dapat membebankan biaya masuk ataupun tidak.

Faktor pendorong yang paling dominan dalam mendorong wisatawan untuk menghadiri event Jazz Gunung Bromo 2018 adalah motivasi fisik dengan presentase 94\%. Mayoritas wisatawan menghadiri Jazz Gunung Bromo
2018 untuk relaksasi sambal mendengarkan alunan musik Jazz. Dengan mendengarkan alunan musik Jazz sambil menikmati pemandangan alam membantu wisatawan untuk rileks. Kegiatan tersebut dianggap sebagai bentuk dari healing time. Faktor penarik yang dominan dari Jazz Gunung Bromo 2018 adalah tempat dan pengisi acara yang sama-sama memiliki presentase tinggi, yaitu $72.5 \%$. Lokasi acara yang berada di pegunungan dengan tinggi $2000 \mathrm{mdpl}$ dan dikelilingi dengan alam menarik wisatawan untuk menghadiri Jazz Gunung Bromo. Rangkaian musisi/pengisi acara dari dalam maupun luar negeri juga merupakan faktor penarik yang mampu mendatangkan wisatawan.

\section{DAFTAR PUSTAKA}

Badan Pusat Statistik. 14 Maret 2018. https://www.bps.go.id/subject/16/pariwi sata.html

Campbell, Richard Bret. 2011. A Sense of Place: Examining music-based tourism and its implications in destination venue placement. University of Nevada Las Vegas.

CNN. 7 Maret 2017.

https://www.cnnindonesia.com/gayahidup/20170429184052-307-

211145/genjot-wisatawan-kemenpar- dukungmice-2017

CNN. 9 April 2018.

https://www.cnnindonesia.com/gayahidup/20180309095041-269-

281666/wisata-musik-potensi-yang- diabaikan CNN. 5 Mei 2018.

https://www.cnnindonesia.com/gayahidup/20170819154512-307-

235867/kolaborasi-3-penggagas-tenar- suguhkanjazz-gunung-bromo

Dann, Graham M.S.. 1977. Anomie, EgoEnhancement and Tourism. [Jurnal]. Annals of Tourism Research Vol. IV, No.4.

Gibson, Chris, John Connell. 2005. Music and Tourism: On the Road Again. Multilingual Matters.

Ijen Summer Jazz. 24 Mei 2018. http://www.ijensummerjazz.com Ismayanti. 2010. Pengantar Pariwisata. Jakarta (ID): PT Grasindo.

$\begin{array}{llll}\text { Java Jazz. } & 7 & \text { Maret } 2018\end{array}$ https://www.javajazzfestival.com

Jazz Gunung. 3 Mei 2018. http://jazzgunung.com/ticket/jazzgunung-bromo-2018

Kompas. $28 \quad$ Mei 2018. https://travel.kompas.com/read/2014/06/ 
26/1747272/Sigit.Pramono.Bank.Fotogr afi.dan.Jazz.Gunung

Miles, Matthew B., A. Michael Huberman. 1992. Analisis Data Kualitatif. Salemba (ID): Penerbit Universitas Indonesia (UI-Press).

Popp, Leanna. 2013. Understanding the Push and Pull Motivations and Itinerary Patterns of Wine Tourists. [Thesis].

Michigan State University.

Republika. 32018.

http://nasional.republika.co.id/berita/nas ional/daerah/18/01/22/p2xnsu280-gus- ipulsektor-pariwisata-andalan- majukanekonomi-jatim

Ross, Glenn F. 1998. Psikologi Pariwisata. Jakarta (ID): Yayasan Obor Indonesia.

Said, Jumrin, Maryono. 2018. Motivation and Perception of Tourists as Push and Pulls Factors to Visit National Park. [Jurnal]. E3S Web of Conferences 31 .

Sari, Fitria. 2014. Tinjauan Terhadap Motivasi Wisatawan Berkunjung ke Objek Wisata Air Terjun Aek Martua Kabupaten Rokan Hulu Provinsi Riau. [Jurnal]. Jom FISIP Volume 1 No.2.

Sugiyono. 2018. Metode Penelitian Kuantitatif, Kualitatif, dan $R \& D$. Bandung (ID): Alfabeta.

Swarbrooke, John. 2002. The Development and Management of Visitor Attractions. Great Britain (GB): Butterworth- Heinemann.

Tung, Vincent Wing Sun, \& J. R. Brent Ritchie. 2011. Exploring the Essence of Memorable Tourism Experience. [Jurnal]. Annals of Tourism Research, Vol. 38, No. 4.

UK Music. 2017. The Contribution of Live Musicto the UK Economy. United Kingdom (UK): UK Music.

Wibisono, Aunurrahman. 2016. Potensi Pariwisata Musik Sebagai Alternatif Pariwisata Baru di Indonesia (Contoh Kasus Java Jazz). [Tesis]. Yogyakarta (ID): Universitas Gadjah Mada 
